\title{
Tingkat ketahanan pangan rumah tangga dengan status gizi balita di daerah rawan pangan Kabupaten Indramayu
}

\author{
The relationship between household food security level with under five children's nutritional \\ status in family of food scarcity-area in Indramayu Sub-district
}

\author{
Slamet Rohaedi', Madarina Julia², I Made Alit Gunawan ${ }^{3}$
}

\begin{abstract}
Background: Nutrition is the main pillar of health and welfare of human's life cycle. The building of quality human resources that are healthy, smart and productive depends on numerous factors; one most essential is the fulfillment of nutritious food. Food security is a problem that has become topic of discussion because it is related to human right and development of human resources.

Objectives: To analyze association between level of food security in the household and nutritional status of underfives.

Methods: The study used analytical observational approach with cross-sectional design. Population of the study were households at high risk food scarcity area of Indramayu District that had underfives. Subject of the study that became part of the population were underfives of 24-60 months old. Samples were taken randomly, comprising 160 underfives. Data analysis was made in stages using statistical test to prove the hypothesis. The test used univariate with frequency distribution, bivariate with chi-square and Mantel-Haenzel and multivariate with logistic correlation regression.

Results: There was significant association between food security of the household and nutrition status of underfives OR=9.5 (C/ 95\%) and $p<0.0001$.

Conclusions: There was significant association between level of food security of the household and nutritional status of underfives.
\end{abstract}

KEYWORS: food security, household, underfives, nutritional status

\begin{abstract}
ABSTRAK
Latar belakang: Gizi adalah pilar utama dari kesehatan dan kesejahteraan sepanjang siklus kehidupan. Terbentuknya sumber daya manusia yang berkualitas, yaitu sumber daya manusia yang sehat, cerdas, dan produktif ditentukan oleh berbagai faktor. Salah satu faktor yang sangat esensial adalah terpenuhinya kebutuhan pangan yang bergizi. Ketahanan pangan merupakan salah satu permasalahan yang menjadi agenda pembicaraan karena berkaitan dengan hak azasi manusia, pembangunan sumber daya manusia.

Tujuan: Menganalisis hubungan antara tingkat ketahanan pangan rumah tangga dengan status gizi anak balita.

Metode: Penelitian ini adalah penelitian analitik dengan jenis penelitian observasional dan rancangan penelitian cross sectional (potong-lintang). Populasi penelitian adalah rumah tangga di daerah rawan pangan Kabupaten Indramayu yang memiliki balita. Subjek penelitian yang merupakan bagian dari populasi adalah anak balita usia 24-60 bulan. Cara pengambilan sampel dalam penelitian ini dengan menggunakan simple random sampling. Besarnya sampel dalam penelitian ini adalah 160 anak balita. Analisis data dilakukan secara bertahap, yaitu analisis data dilakukan dengan uji statistik untuk
\end{abstract}

\footnotetext{
${ }^{1}$ Akademi Keperawatan Pemerintah Kabupaten Indramayu

2 Bagian IImu Kesehatan Masyarakat, FK UGM, Yogyakarta

${ }^{3}$ Politeknik Kesehatan, Kementrian Kesehatan Republik Indonesia, Propinsi DIY
} 
membuktikan hipotesis penelitian. Teknik uji statistik yang digunakan adalah univariat dengan distribusi frekuensi, bivariat dengan kai-kuadrat, stratifikasi-Mantel-Haenszel, sedangkan multivariat dengan regresi korelasi logistik.

Hasil: Ketahanan pangan tingkat rumah tangga dengan status gizi anak balita memiliki hubungan yang bermakna dengan OR=9,5 (Cl 95\%) dan p<0,0001.

Kesimpulan: Terdapat hubungan yang bermakna antara tingkat ketahanan pangan rumah tangga dengan status gizi balita

KATA KUNCI: ketahanan pangan rumah tangga, status gizi, anak balita

\section{PENDAHULUAN}

Gizi adalah pilar utama dari kesehatan dan kesejahteraan sepanjang siklus kehidupan. Terbentuknya sumber daya manusia yang berkualitas, yaitu sumber daya manusia yang sehat, cerdas, dan produktif ditentukan oleh berbagai faktor. Salah satu faktor yang sangat esensial adalah terpenuhinya kebutuhan pangan yang bergizi, ketahanan pangan merupakan salah satu permasalahan yang menjadi agenda pembicaraan karena berkaitan dengan hak azasi manusia, pembangunan sumber daya manusia (1). Ketahanan pangan dalam rumah tangga didefinisikan sebagai terpenuhinya asupan nutrisi yang adekuat, ketersediaan makanan, serta kemampuan keluarga untuk memenuhi pangan secara sosial (2).

Jumlah rumah tangga miskin di Kabupaten Indramayu adalah 169.720 dan sebagian besar bekerja sebagai buruh tani sebanyak 252.012 yang tersebar di 25 kecamatan. Buruh nelayan sebanyak 97.076 tersebar di 6 kecamatan di wilayah Kabupaten Indramayu (3). Berdasarkan hasil pemantauan status gizi tahun 2009 oleh Dinas Kesehatan Kabupaten Indramayu dilaporkan bahwa anak balita yang mengalami kurang gizi anak secara keseluruhan mencapai 14.625 dari 132.167 anak balita, sehingga prevalensi kurang gizi di Kabupaten Indramayu tahun 2009 adalah $11,17 \%$. Sementara itu, ada 6 wilayah kerja puskesmas ditemukan kasus kurang gizi yang cukup tinggi pada anak balita yaitu di Puskesmas Plumbon (prevalensi kurang gizi 16,9\%), Jatibarang (prevalensi kurang gizi 15,12\%), Terisi (prevalensi kurang gizi 12\%), Losarang (prevalensi kurang gizi 14,51\%), Cidempet (prevalensi kurang gizi 16,61\%), Juntinyuat (prevalensi kurang gizi 18,28\%) (4).

\section{BAHAN DAN METODE}

Penelitian ini adalah penelitian analitik dengan jenis penelitian observasional dan rancangan penelitian cross sectional (potong-lintang). Penelitian ini menggunakan suatu pendekatan yaitu analisis kuantitatif.

Populasi penelitian adalah rumah tangga di daerah desa pantai dan desa agraria di Kabupaten Indramayu yang memiliki anak usia 24-60 bulan. Penelitian dilakukan di 6 kecamatan dalam lingkup wilayah puskesmas dengan angka kejadian kurang gizi pada anak balita yang cukup tinggi. Pemilihan sampel dengan metode acak sederhana (simple random sampling) dilakukan untuk memilih sampel dari kerangka sampling. Total ukuran sampel pada studi ini adalah 153-162 rumah tangga yang memiliki anak balita.

Jenis data yang dikumpulkan dalam penelitian ini dapat digolongkan menjadi dua, yaitu data primer dan data sekunder. Data primer akan dikumpulkan melalui wawancara menggunakan kuesioner dan pengamatan personal terhadap responden sedangkan data sekunder akan dikumpulkan dari kantor dinas pemerintah kabupaten dan desa. Data dianalisis dan disajikan secara deskriptif.

\section{HASIL}

Distribusi frekuensi ketahanan pangan tingkat rumah tangga disajikan dalam Tabel 1 berdasarkan karakteristik subjek penelitian menurut variabel status ekonomi, pendidikan ibu, sanitasi dan tempat tinggal.

Data skor ketahanan pangan tingkat rumah tangga serta status gizi diuji normalitasnya dengan Kolmogorov Smirnov. Hasil uji dari kedua variabel 
Tabel 1. Distribusi frekuensi status gizi balita, ketahanan pangan tingkat rumah tangga dan karakteristik subjek penelitian

\begin{tabular}{lcc}
\hline \multicolumn{1}{c}{ Variabel } & $\mathbf{n}$ & $\%$ \\
\hline Status gizi & & \\
$\quad$ Baik $(\geq-2$ SD) & 43 & 26,88 \\
$\quad$ Kurang (<-2 SD) & 117 & 73,12 \\
Ketahanan pangan & & \\
$\quad$ Tahan pangan $<70 \%$ & 28 & 17,50 \\
$\quad$ Rawan pangan $>70 \%$ & 132 & 82,50 \\
Pendidikan ibu & & \\
$\quad$ Rendah & 126 & 78,75 \\
$\quad$ Tinggi & 34 & 21,25 \\
Tempat tinggal & & \\
$\quad$ Desa pantai & 68 & 42,50 \\
$\quad$ Desa agraria & 92 & 57,50 \\
Status ekonomi & & \\
$\quad$ Tinggi & 22 & 13,80 \\
$\quad$ Rendah & 138 & 86,20 \\
Sanitasi & & \\
$\quad$ Baik & 12 & 7,50 \\
$\quad$ Kurang & 148 & 92,50 \\
\hline
\end{tabular}

tersebut tidak normal $(p<0,001)$. Hubungan antara ketahanan pangan dengan status gizi dapat dilihat pada Tabel 2.

Analisis stratifikasi dan uji Mantel-Haenszel dilakukan untuk melihat pengaruh variabel luar yaitu tempat tinggal, sanitasi, pendidikan ibu, dan status ekonomi yang dianggap variabel pengganggu terhadap variabel ketahanan pangan dan status gizi balita.
Pada Tabel 3 menunjukkan keluarga yang rawan pangan dengan status ekonomi tinggi memiliki 10 balita dengan status gizi baik. Keluarga yang rawan pangan dengan ekonomi rendah memiliki 102 balita gizi kurang. Hal ini menunjukkan bahwa rumah tangga yang memiliki status ekonomi rendah dengan keadaan rawan pangan menentukan terjadinya status gizi kurang pada balita. Meskipun demikian, dalam penelitian ini ditemukan keluarga dengan kondisi rawan pangan tetapi memiliki balita dengan status gizi baik disebabkan keluarga memiliki status ekonomi tinggi. Dengan demikian dapat diketahui bahwa status ekonomi mempengaruhi ketahanan pangan dan status gizi balita. Status ekonomi dinyatakan sebagai effect modifier bagi hubungan antara ketahanan pangan dengan status gizi balita. Selanjutnya, dari hasil uji MantelHaenszel didapatkan perbedaan COR (crude odds ratio) dan ORMH (odds ratio Mantel-Haenszel) sebesar 39\%, sehingga status ekonomi merupakan variabel perancu bagi hubungan antara ketahanan pangan dengan status gizi balita.

Hasil uji stratifikasi pada Tabel $\mathbf{3}$ memperlihatkan OR (odds ratio) pada pendidikan ibu yang rendah berbeda dengan OR pendidikan ibu yang tinggi. Pada Tabel 3, pendidikan ibu yang rendah dengan kondisi rumah tangga rawan pangan didapatkan sebanyak 93 balita dengan status gizi kurang, namun dalam penelitian ini

Tabel 2. Hubungan antara status gizi dengan ketahanan pangan, dan variabel luar

\begin{tabular}{|c|c|c|c|c|c|}
\hline \multirow[b]{2}{*}{ Variabel } & \multicolumn{2}{|l|}{ Status gizi } & \multirow[b]{2}{*}{ Total } & \multirow[b]{2}{*}{$\begin{array}{c}\text { OR } \\
(95 \% \mathrm{Cl})\end{array}$} & \multirow[b]{2}{*}{$\mathbf{p}$} \\
\hline & $\begin{array}{c}\text { Baik } \\
\text { n (\%) }\end{array}$ & $\begin{array}{c}\text { Kurang } \\
\text { n (\%) }\end{array}$ & & & \\
\hline \multicolumn{6}{|l|}{ Ketahanan pangan } \\
\hline Tahan pangan $<70 \%$ & $19(67,9 \%)$ & $9(32,1 \%)$ & $28(100 \%)$ & 9,5 & 0,0001 \\
\hline Rawan pangan $>70 \%$ & $24(18,2 \%)$ & $108(81,8 \%)$ & $132(100 \%)$ & $(3,83-23,56)$ & \\
\hline \multicolumn{6}{|l|}{ Pendidikan ibu } \\
\hline Rendah & $28(22,2 \%)$ & $97(77,8 \%)$ & $126(100 \%)$ & 0,36 & 0,0001 \\
\hline Tinggi & $15(44,1 \%)$ & $19(55,9 \%)$ & $34(100 \%)$ & $(0,16-0,80)$ & \\
\hline \multicolumn{6}{|l|}{ Tempat tinggal } \\
\hline Desa pantai & $21(30,9 \%)$ & $47(69,1 \%)$ & $68(100 \%)$ & 1,42 & 0,33 \\
\hline Desa agraria & $22(53,5 \%)$ & $70(46,5 \%)$ & $92(100 \%)$ & $(0,70-2,87)$ & \\
\hline \multicolumn{6}{|l|}{ Status ekonomi } \\
\hline Tinggi & $14(63,6 \%)$ & $8(36,4 \%)$ & $22(100 \%)$ & 6,58 & 0,0001 \\
\hline Rendah & $29(21 \% \%)$ & $109(79 \%)$ & $138(100 \%)$ & $(2,52-17,19)$ & \\
\hline \multicolumn{6}{|l|}{ Sanitasi } \\
\hline Baik & $9(75 \%)$ & $3(25 \%)$ & $12(100 \%)$ & 10,05 & 0,0001 \\
\hline Kurang & $34(23 \%)$ & $114(77 \%)$ & $148(100 \%)$ & $(2,58-39,20)$ & \\
\hline
\end{tabular}


Tabel 3. Stratifikasi variabel luar dengan ketahanan pangan rumah tangga terhadap status gizi

\begin{tabular}{|c|c|c|c|c|c|c|c|c|}
\hline \multirow{2}{*}{ Variabel luar } & \multirow{2}{*}{ Ketahanan pangan } & \multicolumn{2}{|c|}{ Status gizi } & \multirow{2}{*}{$\begin{array}{c}\text { OR } \\
\text { adjusted }\end{array}$} & \multirow{2}{*}{$\begin{array}{c}\text { OR } \\
\text { crude }\end{array}$} & \multirow{2}{*}{$\begin{array}{c}\text { OR } \\
M-H\end{array}$} & \multirow{2}{*}{$\begin{array}{l}\text { (OR MH- } \\
\text { COR) \% }\end{array}$} & \multirow{2}{*}{$\mathbf{p}$} \\
\hline & & Baik & Kurang & & & & & \\
\hline \multicolumn{9}{|l|}{ Status ekonomi } \\
\hline \multirow[t]{2}{*}{ Tinggi } & Tahan pangan & 4 & 2 & \multirow{2}{*}{1,20} & \multirow{4}{*}{9,50} & \multirow{4}{*}{13,22} & & 0,865 \\
\hline & Rawan pangan & 10 & 6 & & & & 3,72 & \\
\hline \multirow[t]{2}{*}{ Rendah } & Tahan pangan & 15 & 7 & \multirow[b]{2}{*}{15,61} & & & $39 \%$ & 0,0001 \\
\hline & Rawan pangan & 14 & 102 & & & & & \\
\hline \multicolumn{9}{|l|}{ Pendidikan ibu } \\
\hline \multirow[t]{2}{*}{ Rendah } & Tahan pangan & 18 & 5 & \multirow{2}{*}{33,48} & \multirow{4}{*}{9,50} & \multirow{4}{*}{12,22} & \multirow{4}{*}{$\begin{array}{l}2,72 \\
29 \%\end{array}$} & 0,0001 \\
\hline & Rawan pangan & 10 & 93 & & & & & \\
\hline \multirow[t]{2}{*}{ Tinggi } & Tahan pangan & 1 & 4 & \multirow{2}{*}{0,27} & & & & 0,25 \\
\hline & Rawan pangan & 14 & 15 & & & & & \\
\hline \multicolumn{9}{|l|}{ Sanitasi } \\
\hline \multirow[t]{2}{*}{ Baik } & Tahan pangan & 3 & 0 & \multirow{2}{*}{000} & \multirow{4}{*}{9,50} & \multirow{4}{*}{10,30} & \multirow{4}{*}{$\begin{array}{c}0,80 \\
8 \%\end{array}$} & 0,29 \\
\hline & Rawan pangan & 6 & 3 & & & & & \\
\hline \multirow[t]{2}{*}{ Kurang } & Tahan pangan & 16 & 9 & \multirow{2}{*}{10,37} & & & & 0,0001 \\
\hline & Rawan pangan & 18 & 105 & & & & & \\
\hline \multicolumn{9}{|l|}{ Tempat tinggal } \\
\hline \multirow[t]{2}{*}{ Desa pantai } & Tahan pangan & 11 & 8 & \multirow{2}{*}{5,67} & & & & 0,07 \\
\hline & Rawan pangan & 10 & 39 & & 9,50 & 12,40 & $\begin{array}{l}2,90 \\
31 \%\end{array}$ & \\
\hline Desa agraria & Tahan pangan & 8 & 1 & 3943 & & & & 0,0001 \\
\hline & Rawan pangan & 14 & 69 & 39,43 & & & & \\
\hline
\end{tabular}

ditemukan keluarga dengan kondisi rawan pangan tetapi memiliki balita dengan status gizi baik ada 14 disebabkan keluarga (ibu) memiliki pendidikan tinggi, sehingga dapat diketahui bahwa pendidikan ibu mempengaruhi ketahanan pangan dan status gizi balita. Pendidikan ibu sebagai effect modifier bagi hubungan antara ketahanan pangan dengan status gizi balita. Selanjutnya, dari hasil uji MantelHaenszel didapatkan perbedaan COR dengan ORMH sebesar $29 \%$ sehingga pendidikan ibu merupakan variabel perancu bagi hubungan antara ketahanan pangan dengan status gizi balita.

Hasil uji stratifikasi pada Tabel 3 memperlihatkan OR antara sanitasi baik dengan OR sanitasi kurang berbeda. Rumah tangga dengan sanitasi kurang dan kondisi rumah tangga rawan pangan didapatkan sebanyak 114 balita dengan status gizi kurang, sehingga dapat diketahui kondisi sanitasi mempengaruhi ketahanan pangan dan status gizi balita. Sanitasi sebagai effect modifier bagi hubungan antara ketahanan pangan dengan status gizi balita. Selanjutnya dari hasil uji MantelHaenszel didapatkan perbedaan COR ORMH sebesar $8 \%$, sehingga sanitasi bukan merupakan variabel perancu bagi hubungan antara ketahanan pangan dengan status gizi balita.
Hasil ujistratifikasi pada Tabel 3 memperlihatkan OR pada desa pantai berbeda dengan OR desa agraria. Pada desa agraria dengan kondisi rumah tangga rawan pangan didapatkan sebanyak 70 balita dengan status gizi kurang, sedangkan pada desa pantai didapatkan sebanyak 47 balita dengan status gizi kurang. Dengan demikian dapat diketahui bahwa tempat tinggal mempengaruhi hubungan ketahanan pangan dan status gizi balita dan tempat tinggal disini sebagai effect modifier bagi hubungan antara ketahanan pangan dengan status gizi balita. Selanjutnya, dari hasil uji Mantel-Haenszel didapatkan perbedaan $\mathrm{COR}$ dan ORMH sebesar $31 \%$ sehingga tempat tinggal merupakan variabel perancu bagi hubungan antara ketahanan pangan dengan status gizi balita.

Melihat hasil analisis Tabel 3, dapat dilihat bahwa variabel status ekonomi, pendidikan, dan tempat tinggal memiliki kecenderungan sebagai variabel pengganggu karena nilai koefisien pengganggu $>10 \%$, sedangkan variabel sanitasi tidak sebagai pengganggu terhadap variabel status gizi karena nilai koefisien pengganggu $<10 \%$.

Analisis multivariat ditujukan untuk menganalisis hubungan antara variabel bebas dan variabel pengganggu terhadap variabel 
terikat, setelah sebelumnya mengontrol variabel yang mempunyai keterkaitan yang signifikan pada analisis bivariat (Tabel 2) dan memiliki kecenderungan sebagai variabel pengganggu (Tabel 3). Variabel tersebut di antaranya adalah ketahanan pangan, status ekonomi, dan pendidikan ibu. Untuk mengujinya adalah dengan melakukan uji analisis regression correlation logistic dengan tingkat kemaknaan $p<0,05$.

Tabel 4. Hasil analisis regresi logistik antara ketahanan pangan, status ekonomi, dan pendidikan ibu terhadap status gizi

\begin{tabular}{lcc}
\hline \multicolumn{1}{c}{ Variabel } & $\begin{array}{c}\text { OR } \\
\mathbf{( 9 5 \%} \mathbf{~ C l )}\end{array}$ & $\mathbf{p}$ \\
\hline Ketahanan pangan & $0,09(0,03-0,24)$ & 0,0001 \\
Status ekonomi & $0,20(0,06-0,65)$ & 0,0070 \\
Pendidikan ibu & $2,17(0,78-6,05)$ & 0,1370 \\
\hline
\end{tabular}

Pada Tabel 4 terlihat bahwa variabel ketahanan pangan dan status ekonomi memiliki hubungan signifikan dengan status gizi balita $(p<0,05)$.

\section{BAHASAN}

\section{Hubungan antara ketahanan pangan tingkat rumah tangga dengan status gizi anak balita}

Hubungan antara ketahanan pangan tingkat rumah tangga dengan status gizi anak balita dengan mengacu pada Tabel 2 dari hasil uji kai-kuadrat dengan OR = 9,5 $(95 \% \mathrm{Cl})$ dan $p<0,0001$ dimaknai bahwa ketahanan pangan mempengaruhi status gizi pada anak balita. Dalam penelitian ini, dikemukakan adanya data aktual yaitu pada Tabel 2 terdapat keluarga yang rawan pangan dengan balita status gizi kurang sebanyak $81,8 \%$. Hal ini diduga penyebabnya adalah pola makan dan asupan makan anak yang kurang baik terkait dengan kebiasaan keluarga yang memberi makan anaknya hanya dengan nasi/bubur dengan kuah sayur atau kadang dengan garam saja. Kadang jika ada ada daging/ikan diberikan pada anak balita (jika ada persediaan) dari hasil memancing di sungai atau berburu ikan di laut.

Keluarga dengan rawan pangan pada lokasi penelitian ini dalam memenuhi pangan rumah tangga memiliki status gizi balita baik sebesar $18,2 \%$. Hal ini kemungkinan disebabkan oleh distribusi makanan dalam rumah tangga sudah baik dan kemungkinan juga keluarga dapat mengganti kebiasaan makan seperti nasi dengan singkong, ubi jalar, atau talas dan itu bisa didapatkan dari hasil berkebun. Akan tetapi, jika mereka tidak memiliki lahan kebun mereka bisa membeli di pasar. Namun demikian, tidak semua kebutuhan pangan itu terpenuhi dengan membeli karena sebagian besar keluarga di lokasi penelitian ini dengan status ekonomi rendah $(86,2 \%)$.

Hasil penelitian ini tidak sejalan dengan penelitian di Kabupaten Tanah Laut, Kalimantan Selatan yang menyatakan bahwa ketahanan pangan keluarga berdasarkan tingkat konsumsi energi dan protein tidak berhubungan dengan status gizi balita (5).

Ketidaktahanan pangan dalam keluarga juga dapat mengakibatkan penurunan fungsi-fungsi fisik dan psikososial, serta rendahnya prestasi akademik (6). Terdapat dua faktor yang terkait langsung dengan masalah gizi khususnya gizi buruk atau kurang, yaitu intake zat gizi yang bersumber dari makanan dan infeksi penyakit. Kedua faktor yang saling mempengaruhi tersebut terkait dengan berbagai faktor penyebab tidak langsung yaitu ketahanan dan keamanan pangan.

\section{Pengaruh variabel luar terhadap status gizi Tempat tinggal}

Penelitian ini menunjukkan bahwa variabel tempat tinggal tidak memiliki hubungan yang bermakna dengan status gizi. Namun demikian, uji stratifikasi dan uji Mantel-Haenszel menunjukkan tempat tinggal mempengaruhi hubungan ketahanan pangan dan status gizi balita sebagai effect modifier bagi hubungan antara ketahanan pangan dengan status gizi balita, sedangkan tempat tinggal merupakan variabel perancu bagi hubungan antara ketahanan pangan dengan status gizi balita. Hal ini sama dengan penelitian sebelumnya di Afrika yang mendapatkan gangguan nutrisi pada anak balita berhubungan erat dengan karakteristik orang tua (ibu) yaitu dengan melihat jumlah anak yang dilahirkan, pendidikan ibu, akses tempat tinggal terhadap ketersediaan pangan, distribusi pangan, serta dengan pelayanan kesehatan (7). 


\section{Pendidikan ibu}

Berdasarkan Tabel 2 diketahui variabel pendidikan ibu, ada signifikasi baik secara statistik maupun praktis. Hal ini bisa dikatakan terdapat hubungan antara pendidikan terhadap status gizi balita, sebagaimana ditunjukan dari uji stratifikasi dan uji Mantel-Haenszel dalam penelitian ini bahwa pendidikan ibu disini sebagai effect modifier bagi hubungan antara ketahanan pangan dengan status gizi balita. Selanjutnya, dari hasil uji Mantel-Haenzel didapatkan perbedaan COR dengan ORMH sebesar $29 \%$, sehingga pendidikan ibu merupakan variabel perancu bagi hubungan antara ketahanan pangan dengan status gizi balita. Tingkat pendidikan yang rendah (pendidikan ibu) memiliki pengaruh yang kuat terhadap status gizi kurang pada balita, kemungkinan hal ini disebabkan ibu rumah tangga dalam penelitian ini (dengan pendidikan yang rendah) sebagian besar tidak bekerja.

Dalam penelitian ini, diketahui bahwa tingkat pendidikan (pendidikan ibu) memiliki hubungan yang kuat terhadap status kesehatan (status gizi balita). Lingkungan hidup dapat berpengaruh terhadap apa dan berapa banyak penduduk mengonsumsi pangan serta terhadap status gizinya. Kurang makan dan kurang gizi karena berbagai faktor seperti rendahnya persediaan pangan, pendidikan, serta kondisi kesehatan dapat menimbulkan dampak yang serius dan berakhir lama pada kesehatan tubuh individu dan keluarga. Dengan demikian dapat diketahui bahwa pengetahuan dan pendidikan orang tua sangat penting dalam menentukan status gizi keluarga, karena pendidikan seseorang dapat membantu sampainya informasi tentang kesehatan juga gizi, sehingga kurangnya pendidikan merupakan penyebab tidak langsung timbulnya masalah gizi pada anak. Hal ini sesuai dengan penelitian sebelumnya bahwa partisipasi orang tua (ibu), pendidikan, dan lingkungan keluarga mempunyai peran yang kuat dalam pencegahan masalah gizi terhadap anak. Dalam penelitian mengenai hubungan pendidikan orang tua dan status gizi pada anak di negara berkembang, di negara Vietnam, dan India proporsi anak berstatus gizi rendah banyak ditemukan dalam kelompok ibu yang berpendidikan rendah (sekolah dasar) dan tidak sekolah (8).

\section{Status ekonomi}

Variabel status ekonomi penelitian ini merupakan effect modifier bagi hubungan antara ketahanan pangan dengan status gizi balita dan juga sebagai variabel perancu bagi hubungan antara ketahanan pangan dengan status gizi balita. Dengan demikian sebagian besar rumah tangga dalam penelitian tergolong tidak mampu, sehingga ketahanan pangan dan status gizi balita dipengaruhi status ekonomi. Keluarga dari kelompok sosioekonomi rendah mungkin kurang memiliki pengetahuan atau sumber daya yang diperlukan untuk memberikan lingkungan yang aman, menstimulasi, dan kaya gizi yang membantu perkembangan optimal (9).

Menurut hasil penelitian yang dilakukan sebelumnya diketahui bahwa krisis ekonomi di Indonesia berpengaruh terhadap pendapatan, sehingga mengakibatkan masyarakat mengalami penurunan daya beli dan penyediaan pangan di rumah tangga. Hal ini menyebabkan asupan makanan pada anak akan menjadi kurang (10).

Dari hasil penelitian diketahui bahwa ketidaktahanan pangan dalam suatu rumah tangga dipengaruhi oleh status ekonomi sehingga dapat menyebabkan kemampuan untuk memenuhi kebutuhan pangan menjadi rendah dan pada akhirnya status gizi pada anak juga menurun. Hal ini dapat berpengaruh terhadap pertumbuhan dan perkembangan anak yang menjadi tidak optimal (11).

\section{Sanitasi}

Dalam penelitian ini diketahui bahwa kondisi sanitasi mempengaruhi ketahanan pangan dan status gizi balita sebagai effect modifier, namun bukan merupakan variabel perancu bagi hubungan antara ketahanan pangan dengan status gizi balita.

Dalam penelitian ini, diketahui kondisi lingkungan fisik dan sanitasi akan mempengaruhi manusia yang tinggal di sekitarnya. Kondisi lingkungan fisik yang tidak memadai dan tidak sehat juga merupakan salah satu penyebab tidak langsung timbulnya masalah gizi terutama pada anak. Begitupula dalam hal sanitasi makanan, ditemukan 
masih ada keluarga yang tidak memperhatikan higiene makanan dan minuman, seperti minum air yang tidak dimasak, tidak menyimpan makanan dan minuman di tempat tertutup seperti lemari makan. Bila makanan atau minuman tersebut tidak disimpan atau ditutup, kemungkinan akan tercemar oleh udara kotor atau terkontaminasi kuman berbahaya (patogen) yang dibawa oleh misalnya media lalat. Oleh karena itu, menurut hasil penelitian untuk mendapat manfaat yang optimal dari makanan perlu dijaga sanitasi dan higienisnya (12). Makanan yang sehat harus dijaga agar tetap sehat supaya tidak terkontaminasi oleh zat-zat yang merugikan.

Upaya promosi kesehatan anak baiknya ditekankan pada peningkatan kesehatan lingkungan, sebab secara tidak langsung lingkungan dapat menjadi penyebab terjangkitnya penyakit pada anak-anak (13). Kegiatan sanitasi lingkungan dalam pengendalian vector merupakan salah satu upaya kesehatan yang diselenggarakan untuk mewujudkan kualitas lingkungan yang sehat. Upaya pengendalian vector tersebut dilaksanakan secara terintegrasi dengan berbagai upaya pokok dalam pelaksanaan penyehatan dan pengamanan substansi lingkungan. Hal ini sesuai juga dengan penelitian sebelumnya yang menyatakan bahwa masalah gizi tidak hanya dipengaruhi oleh ketidakseimbangan asupan makanan, tetapi juga dipengaruhi oleh penyakit infeksi dan kesehatan lingkungan (14).

\section{Hasil uji regresi antara status gizi dengan variabel bebas dan variabel pengganggu}

Berdasar hasil uji statistik pada analisis bivariat, didapatkan tiga variabel yang diduga sebagai faktor-faktor yang berkaitan terhadap status gizi balita yakni: ketahanan pangan, status ekonomi, dan pendidikan ibu. Setelah dilakukan uji regresi korelasi logistik, diketahui di antara ketiga variabel tersebut, ketahanan pangan tingkat rumah tangga dan status ekonomi yang memiliki hubungan yang bermakna dengan status gizi balita (Tabel 4) dengan nilai OR=0,09 untuk ketahanan pangan dan $\mathrm{OR}=0,204$ untuk status ekonomi. Hal ini dapat dikatakan bahwa ketahanan pangan dapat mempengaruhi peningkatan status gizi balita sebesar 0,09 kali atau 9\%. Status ekonomi memiliki kontribusi atau pengaruh terhadap peningkatan status gizi balita sebesar 0,20 kali atau $20 \%$.

Setelah krisis pangan mulai reda pada tahun 1980-an, terjadi perubahan konsep ketahanan pangan dari unit nasional ke unit yang lebih kecil yakni ketahanan pangan daerah dan tingkat rumah tangga. Dalam penelitian sebelumnya diketahui bahwa anak yang berasal dari keluarga yang tidak tahan pangan memiliki status kesehatan yang lebih rendah $(A O R=1,90,95 \% \mathrm{Cl}: 1,66-2,18)(15)$. Penelitian yang dilakukan di Pulau Jawa (Provinsi Jawa Barat, Jawa Tengah, dan Jawa Timur) diketahui bahwa kondisi kesehatan dan gizi banyak dipengaruhi oleh pola makan atau keragaman gizi individu. Setelah krisis ekonomi, diketahui sekitar $94,2 \%$ rumah tangga di provinsi-provinsi di Pulau Jawa mengalami kecenderungan tidak tahan pangan (10).

\section{KESIMPULAN DAN SARAN}

Ketahanan pangan tingkat rumah tangga sebagian besar rawan pangan. Status gizi balita sebagian besar kurang. Terdapat hubungan yang signifikan antara tingkat ketahanan pangan rumah tangga dengan status gizi balita.

Mengacu pada hasil penelitian, maka dapat dipertimbangkan adanya faktor lain yang mempengaruhi hubungan antara ketahanan dengan status gizi pada anak balita yaitu status ekonomi. Diharapkan penelitian ini bermanfaat bagi Pemerintah Kabupaten Indramayu yaitu dalam usaha untuk meningkatkan ketahanan pangan rumah tangga, status ekonomi, dan status gizi. Hal ini dapat dilakukan melalui upaya perbaikan keadaan ekonomi masyarakat seperti kebijakan program memberdayakan masyarakat untuk mandiri dengan pemberian bantuan modal usaha dan ketrampilan wirausaha pada rumah tangga yang kurang mampu pada wilayah penelitian. Program tersebut diharapkan dapat meningkatkan taraf perekonomian rumah tangga. Dengan meningkatnya taraf ekonomi rumah tangga, diharapkan berbanding lurus dengan peningkatan ketahanan pangan rumah tangga dan status gizi keluarga terutama status gizi balita. Selanjutnya, bagi Dinas kesehatan Kabupaten 
Indramayu, dalam usaha untuk meningkatkan ketahanan pangan rumah tangga dan status gizi balita pada lokasi penelitian diharapkan dapat memberikan program pemberian makanan sehat bagi balita yang kurang gizi serta penyuluhan kesehatan secara berkesinambungan kepada orang tua akan pentingnya makanan yang baik dan bergizi. Adapun tempat penyuluhan dapat dilakukan di Posyandu dan Puskesmas.

\section{RUJUKAN}

1. Pelletier DL, Frongillo EA. Changes in child survival are strongly associated with changes in malnutrition in developing countries. Journal Nutrition 2003; 133:107-119.

2. Casey PH, Simpson PM, Gossett JM, Bogle ML, Champagne CM, Connell C, Harsha D, et al. The association of child and household food insecurity with childhood overweight status. Pediatrics 2006; 118:e1406-e1413.

3. BPS Kabupaten Indramayu. Indramayu dalam angka 2008. Indramayu: BPS Kabupaten; 2008.

4. Dinas Kesehatan Kabupaten Indramayu. Profil Kesehatan Dinas Kesehatan Kabupaten Indramayu Tahun 2010. Indramayu: Dinas Kesehatan Kabupaten Indramayu; 2010.

5. Rahmadi, Sudargo T, Wijanarka A. Perilaku sadar gizi dan ketahanan pangan keluarga serta hubungannya dengan status gizi balita di Kabupaten Tanah Laut Kalimantan Selatan. Jurnal Gizi dan Dietetik Indonesia 2013; I(1): 31-8

6. Jacobs RR, Black MM, Casey PH, Cook JT, Cutts DB, Chilton, M, et al. Household food insecurity: association with at-risk infant and toddler development. Pediatrics 2008; 121:6572.
7. Broeck J, Eeckels R, Massa C. Maternal determinants of child survival in a rural African community. International Jornal epidemoiology 1996; 25:998-100.

8. Moestue H, Huttly S. Adult education and child nutrition: the role of family and comumnity. Journal epidemiology community health 2008 ; 62:153-159.

9. Wong, DL, Whaley, L. Buku ajar keperawatan pediatrik. Jakarta: EGC; 2008.

10. Studdert LJ, Frongillo EA, Valois P. Household food in security was prevalent in Java during Indonesia's economic crisis. Journal Nutrition 2001; 131:2685-269.

11. Milman A, Frongillo EA, Onis MD, Hwang JY. Differential improvement among countries in child stunting is associated with long term development and specific interventions. Journal Nutrition 2005; 135:1415-1422.

12. Wagstaff A, Bustreo F, Bryce J, Claeson M, WHO-World Bank Child Health and Poverty Working Group. Child health: reaching the poor. American Journal Public Health 2004; 94:726-736.

13. Ehiri JE, Prowse JM. Child health promotion in developing countries: the case for integration of environtmental and social intervention. Health Policy Plan 1999; 14:1-10.

14. Silventoinen K, Kaprio J, Lahelma E, Koskenvuo $M$. Relative effect of genetic and enviromental factors on body height differences across birth cohorts among finish men and women. American Journal Public Health. 2000; 90:627-630.

15. Cook JT, Frank DA, Berkowitz C, Black MM, Casey $\mathrm{PH}$, Cutts DB, et al. Food insecurity is associated with adverse health outcomes among human infant and toddlers. Journal Nutrition 2004; 134:1432-1438. 